Astrid Męczkowska-Christiansen

https://doi.org/10.26881/pwe.2019.47.05

ORCID: 0000-0002-4966-7856

Akademia Marynarki Wojennej

a.meczkowska-christiansen@amw.gdynia.pl

Kamila Zdanowicz-Kucharczyk

ORCID: 0000-0002-1637-6307

Mazowiecka Uczelnia Publiczna w Płocku

\title{
Uczeń zdolny w perspektywie dyskursu produkcyjnego. Część II: Świat szkoły ${ }^{1}$
}

\section{Summary}

\section{A talented student in a perspective of the production discourse. Part II: The world of school}

The paper is a continuation and, at the same time, an empirical illustration of considerations regarding the production discourse of a talented student with neoliberal provenance (Męczkowska-Christiansen 2018). The presented analyses are embedded in the perspective of critical discourse analysis and include insight into selected school practices of meeting the challenges of gifted education. They used a variety of data, including document analysis and narrative interviews. As a result of the analyses, the school strategies for "dealing" with talented students were highlighted, emphasizing their exploitative dimension.

Keywords: high ability student, gifted education, production discourse of high ability student

Słowa kluczowe: uczeń zdolny, pedagogika zdolności, produkcyjny dyskurs ucznia zdolnego

Konceptualizacja przedmiotu analiz naukowych - a w tym wypadku mowa o fenomenie „ucznia zdolnego” jako obiekcie zainteresowań psychologii i pedagogiki zdolności - jest zawsze osadzona dyskursywnie, wyłaniając się w polu/polach „interesów konstytuujących poznanie" (Habermas 1985), które - co konsekwentnie ukazywał m.in. Foucault - stanowią refleks interesów politycznych rozumianych jako dążenie do sprawowania różnych form władzy nad rzeczywistością społeczną (Foucault 2006 i in.). W kontekście tej tezy odwołujemy się do produkcyjnego dyskursu ucznia zdolnego jako formy ideacji, a zarazem materializacji neoliberalnego dążenia do ekspansji kalkulatywnych form rozumu pedagogicznego, zorientowanych na wzmacnianie ekonomicznie użytecznej produktywności jednostek wybitnych, a jednocześnie kreowanie nowych elit merytokratycznego społeczeństwa (Margolin 1996; Męczkowska-Christiansen 2018). Taki rodzaj konceptualizacji ucznia zdolnego

1 Artykuł nawiązuje bezpośrednio do tekstu Astrid Męczkowskiej-Christiansen (2018). 
wyznacza ideologiczny rys dominującego dyskursu pedagogii zdolności (giftedness education), obejmującego zarazem pole teorii, badań, jak i praktyk edukacyjnych deklaratywnie zorientowanych na wspieranie rozwoju potencjału uczniów szczególnie uzdolnionych, a określonego mianem produkcyjnego dyskursu ucznia zdolnego (PDUZ).

\section{Intencje badawcze}

Badacze osadzeni w perspektywie PDUZ, planując badania, kierują się przekonaniem o empirycznej obecności fenomenu ucznia zdolnego, traktując je jako zjawisko obiektywnie istniejące, a zarazem poddające się ilościowemu pomiarowi ${ }^{2}$. Z kolei na poziomie praktyk edukacyjnych uczniowie zdolni w szkołach są identyfikowani ze względu na swoje wybitne osiągnięcia lub też poziom IQ; bierze się pod uwagę jednak te walory, które są społecznie uznawane i cenione, a jednocześnie rynkowo ,użyteczne”, z pominięciem wielu z takich, które mogą być wyrazem potrzeb samorealizacyjnych i mogą się ujawnić w całkowicie nieoczekiwanych sytuacjach w ciągu całego życia (Freeman 2012: 12). Z tego powodu w badaniach empirycznych nad problematyką ucznia zdolnego warto brać pod uwagę (co uczyniły autorki) doświadczenia ex post, będące udziałem młodych wybitnych ludzi już po ukończeniu ich kariery szkolnej, niekoniecznie zaś status ,ucznia zdolnego” przypisany im w szkole.

To założenie można odnieść do jednego z komponentów przeprowadzonych przez nas analiz osadzonych w perspektywie krytycznej analizy dyskursu (KAD), gdzie w celu uzyskania wglądu w szkolne doświadczenia młodzieży szczególnie uzdolnionej zastosowano m.in. serię wywiadów biograficznych z osobami spełniającymi kryteria wybitnych osiągnięć edukacyjnych lub edukacyjno-zawodowych ${ }^{3} \mathrm{w}$ miejsce ,tradycyjnych” form doboru opartego na kryterium psychometrycznym. Wywiady miały charakter bezpośredni lub pośredni, przeprowadzano je z wykorzystaniem środków telekomunikacyjnych ze względu na to, że część badanych mieszka lub studiuje za granicą. Objęto nimi 12 osób w wieku 21-30 lat, które niekoniecznie były identyfikowane w szkole jako uczniowie zdolni, oraz osadzono w szerszym kontekście interpretacyjnym, związanym m.in. z wykorzystaniem analizy dokumentów (objęto nią przede wszystkim rekomendacje Ośrodka Rozwoju Edukacji (ORE), realizującego w latach 2010-2014 największy w Polsce program dedykowany pracy szkoły z uczniem zdolnym: „Opracowanie i wdrażanie kompleksowego systemu pracy z uczniem zdolnym"^). Dokonano także wtórnej analizy innych danych empirycz-

\footnotetext{
2 Poszczególne zdolności jednak - jak dowodzi Borland (2003: 112) - są definiowane w zależności od przyjętych wartości, nie zaś od empirycznego wglądu.

3 Wśród badanych znaleźli się m.in.: studentka i absolwentka Uniwersytetu w Oxfordzie, utalentowany programista - laureat kilku znaczących konkursów, pianistka, laureat światowych finałów Odysei Umysłów, osiągający sukcesy edukacyjne studenci prestiżowych kierunków na uczelniach krajowych i zagranicznych. Dobór grupy miał charakter incydentalny, oparty na dostępności. Dobór próby w badaniu jakościowym towarzyszy założeniu o lokalnym i fragmentarycznym zasięgu opisu zjawiska, co pozwala na dostarczenie w wyniku badania stwierdzeń typu „tak bywa” w miejsce „tak (zawsze) jest”.

4 Realizacja projektu miała charakter ogólnopolski, wiązało się to $\mathrm{z}$ wieloma różnorodnymi działaniami, polegającymi m.in. na identyfikacji uczniów uzdolnionych, wspieraniu szkół w procesie pracy z uczniem zdolnym, organizowaniu konkursów i olimpiad przedmiotowych.
} 
nych, m.in. wypowiedzi nauczycielskich uzyskanych metodą wywiadu narracyjnego, zgromadzonych na potrzeby odrębnego badania (Reszke 2018). Całość przyjętej strategii badawczej (wykorzystywanej podczas analiz zaprezentowanych zarówno w niniejszym, jak i poprzednim artykule z tego cyklu) nawiązuje do podejścia określonego mianem krytycznej analizy dyskursu, zorientowanej na krytyczno-hermeneutyczną interpretację i teoretyzację zróżnicowanych grup danych. Pojęcie ,analiza dyskursu” odnosi się do analizy różnorodnych form wypowiedzi, w tym aktów mowy, tekstów, dokumentów etc., w relacji do kontekstów społecznych, w jakich są one generowane. Podstawową rolę w konstytuowaniu się określonych formacji dyskursywnych odgrywa ten ich aspekt, który Michel Foucault określił mianem praktyk dyskursywnych, rozumianych jako ,zbiór anonimowych, historycznych, zawsze określonych w czasie i przestrzeni reguł, które determinowały w danej epoce i dla danego obszaru społecznego, ekonomicznego, geograficznego lub językowego warunki działania funkcji wypowiedzeniowej” (Foucault 1997: 51). Formacje dyskursywne konstruują, regulują i kontrolują wiedzę oraz regulują relacje społeczne, nadając kształt instytucjonalnym formom życia społecznego przez generowanie społecznych/instytucjonalnych ,technologii władzy”, mających znaczenie dla dystrybucji uprawnień, statusów i pozycji w społecznej strukturze władzy (Luke 1997). Reasumując, mimo że KAD za punkt wyjścia bierze szeroko rozumiane wypowiedzi, jej podstawowy przedmiot stanowi nie język, lecz są nimi zjawiska i procesy społeczne.

Przedmiotem przedstawianych analiz jest materializacja dyskursu ucznia zdolnego w obszarze praktyk edukacyjnych polskiej szkoły, a zatem chodziło tu o uzyskanie odpowiedzi na pytanie: W jaki sposób szkoła realizuje wyzwania wspierania rozwoju potencjału ucznia zdolnego? Wziąwszy pod uwagę krytyczny wymiar niniejszego opracowania, tj. wpisanie go w problematykę produkcyjnego dyskursu ucznia zdolnego o wyraźnie eksploatatywnym i instrumentalnym rysie, a zarazem KAD jako zastosowanego podejścia badawczego, zwracamy uwage przede wszystkim na mechanizmy, które mają związek z interesem władzy i dominacji, przybierającymi formy symbolicznej przemocy, eksploatacji i urzeczowienia podmiotów oddziaływań pedagogii zdolności. W tym sensie idea tego opracowania celowo lokuje się raczej w obszarze analiz nad przejawami socjopatologii edukacji (określenie za: Kwieciński 1995), niż daje „,bezstronny” (tj. nienaznaczony przyjętą perspektywą poznawczą) wgląd w pole praktyk pedagogicznych.

\section{Produkcyjny dyskurs ucznia zdolnego: perspektywa szkoły}

\section{Eksploatacja uczniów zdolnych w szkole}

Zgodnie z oficjalnymi założeniami PDUZ szkoła przygotowuje zasoby ludzkie, które będą w przyszłości wykorzystywane dzięki zasileniu przez uczniów kreatywnych kadr gospodarki opartej na wiedzy (Męczkowska-Christiansen 2018). Niemniej uczniowie zdolni czują się eksploatowani już w szkole. Bywają wykorzystywani do wspierania osiągnięć edukacyjnych mniej zdolnych uczniów lub do pomocy nauczycielowi - w zaleceniach 
ORE dotyczących pracy z uczniem zdolnym wielokrotnie pojawiały się strategie (są one także stosowane w szkołach), takie jak: uczenie się w parach, przypisanie uczniowi zdolnemu roli asystenta nauczyciela, zlecenie przygotowania referatu, prezentacji etc. Jak twierdzi Dai (2009: 70), szczególnie eksploatujący w tym aspekcie jest model uczenia się we współpracy (cooperative learning), sprowadzający się w praktyce szkolnej do angażowania uczniów zdolnych do wspierania uczniów o niższych osiągnięciach edukacyjnych. Rodzimym przykładem w tym zakresie może być tutoring uczniowski, rekomendowany przez ekspertów ORE: „Tutoring uczniowski dotyczy pracy ucznia mistrza z innym uczniem - kolegą z klasy lub szkoły w zakresie wybranego przedmiotu, z nastawieniem na rozszerzenie kompetencji obu uczniów i przygotowanie do konkursów" (Mędrzycka, Zawadzka 2011: 9).

Dokonania ucznia zdolnego bywają wykorzystywane w celu wykazywania przez szkołę wybitnych osiągnięć dydaktycznych, przekładających się na eksponowanie wysokiej jakości pracy szkoły i wzrost jej prestiżu w otoczeniu społecznym. Uczeń, który staje się „maszynką do generowania osiągnięć szkoły”, niekiedy czyni to, wyrzekając się własnego rozwoju:

[Byłem] ciągle na olimpiadach matematycznych, ale na inne rzeczy nie mogło być czasu (Uczeń zdolny, doświadczenie ex post [dalej: UZ, ex post]).

Pojechaliśmy do Waszyngtonu na Odyseję Umysłów i przez tydzień siedzieliśmy w hotelu. Niczego nie zobaczyliśmy, trzeba było się przygotowywać do konkursu. Wróciliśmy wykończeni (UZ, ex post).

Niejednokrotnie uczniowie nie otrzymują wsparcia nauczycieli, przygotowując się do zewnętrznych konkursów. Pracują intuicyjnie, szukając po omacku, czynią to w celu zaspokojenia zewnętrznych wobec nich oczekiwań nauczycieli i szkoły:

Więc jakby nauczycielom się wydawało, skoro mam te świetne stopnie ze wszystkiego, to można mnie na takie konkursy wysyłać i nie trzeba mi pomagać, co zapamiętałam sobie na dlugo (UZ, ex post).

Do udziału w zewnętrznych konkursach i olimpiadach przedmiotowych uczniowie bywają wyznaczani przez nauczycieli bez ich zgody, uwzględnienia zainteresowań, uczuć i sytuacji, w której się obecnie znajdują. Liczą się sukces szkoły i uczestnictwo jej uczniów w konkursach, a nie preferencje samych uczniów:

Doskwierało mi to, że typowali mnie do różnych konkursów nawet wtedy, kiedy niespecjalnie chciałam, powiedzmy, ale nie byłam na tyle asertywna, żeby odmówić. Pamiętam, że konkurs z chemii (...) był dla mnie jednym wielkim horrorem. Nikt mnie do tego konkursu nie przygotowywał, musiałam sama się przygotowywać, nie bardzo wiedziałam też jak, natomiast nauczycielka mnie zgłosiła i po prostu na ten konkurs poszłam (UZ, ex post). 
Szkoły realizują także praktyki wykazywania osiągnięć uczniów, których w ogóle nie wspierano w szkole:

Szkoła przypisywała sobie osiągnięcia, z którymi nie miała nic wspólnego. Na przykład ten konkurs literacki. Nic o nim nie wiedzieli, a gdy wygrałam, pojawiło się to na tablicy i w osiągnięciach szkoły. Tak samo z konkursem wokalnym (UZ, ex post $)^{5}$.

\section{Przyspieszanie osiagnięć szkolnych}

Innym aspektem funkcjonowania szkolnego dyskursu produkcyjnego jest nacisk na przyspieszanie osiągnięć ucznia, polegający na szybszej realizacji wymagań wynikających z programu kształcenia i skrócenia okresu nauki (możliwość taką dają aktualne regulacje prawne). W tym wypadku wspieranie osiągnięć uczniów ma charakter mechaniczny i nie przekłada się na jakość ich rozwoju, co świetnie obrazuje powszechne określenie „szybszego przerabiania materiału” (ORE 2009). Oto przykładowa rekomendacja, dotycząca funkcjonowania tzw. klas półrocznych: „Dzieci mają możliwość opanowania w trakcie jednego semestru materiału rozłożonego w normalnym toku nauczania na cały rok, czyli po upływie dwóch semestrów zrealizują materiał z dwóch lat" (Karwowska-Sokołowska 2010: 6-7).

Wyniki badań przeprowadzonych przez Freeman (2012: 16) ostrzegają przed zbyt silnym naciskiem środowiska na uzyskiwanie przez dzieci wysokich wyników w nauce. Niektórzy z uczniów zdolnych, walcząc o wysokie oceny w szkole, ograniczali możliwość swojego rozwoju emocjonalnego, twórczego oraz swoje poczucie wolności. Najbardziej obciążeni byli chłopcy uzdolnieni w naukach matematyczno-fizycznych. Na skutek ,przeskakiwania klas” utracili społeczne relacje z rówieśnikami, czego potem nie umieli już nadrobić.

\section{Powierzchowna identyfikacja i selekcja}

Identyfikacja uczniów zdolnych rodzi problemy w skali globalnej - nie tylko ze względu na ograniczony zasięg narzędzi psychometrycznych, lecz także problematyczny charakter samej konceptualizacji ucznia zdolnego oraz głęboką krytykę praktyk selekcyjnych jako narzędzi generowania i pogłębiania nierówności pomiędzy uczniami oraz wywierania na nich psychologicznej presji (por. Borland 2005). Założenie o starannej identyfikacji i selekcji uczniów zdolnych nie pokrywa się także z rzeczywistymi praktykami polskiej szkoły. Główną strategią jest tu uzyskiwanie informacji o wynikach uczniów w konkursach

\footnotetext{
${ }^{5}$ Co ciekawe, ta sama uczennica miała problemy ze zwalnianiem się z niektórych zajęć szkolnych w celu uczestnictwa w zajęciach w szkole muzycznej. Ponieważ nie wykazywała się zadowalającymi osiągnięciami szkolnymi w ramach niektórych przedmiotów, pewnego dnia usłyszała od wychowawcy, że „szkoła muzyczna” jest (wyłącznie) dla dzieci zdolnych - najpierw należy sobie dobrze radzić z edukacją obowiązkową.
} 
i olimpiadach oraz pozostałych osiągnięciach pozaszkolnych. Nauczyciele na ogół nie dzielą się z innymi nauczycielami wiedzą o uzdolnieniach uczniów (Ponchała 2017). Deklarują stosowanie bieżącej obserwacji klasyfikowanej przez badaczy jako „nieskodyfikowa selekcja miękka", a jedynymi mierzalnymi strategiami identyfikacji uczniów zdolnych stosowanymi w szkołach ponadgimnazjalnych okazał się wynik rekrutacji wstępnej (ORE 2011: 40). Niekiedy nauczyciele dokonują selekcji także w sposób naznaczony błędną atrybucją: w ich przekonaniu zdolni są ci, którzy „są grzeczni” i mają wysokie oceny. W kwestii identyfikowania uzdolnień bywa, że przeoczani są uczniowie „podwójnie wyjątkowi”, a zatem tacy, którzy przejawiają wysokie uzdolnienia i zarazem trudności w pewnych obszarach uczenia się:

Moja mama na wywiadówce usłyszała, że w klasach IB nie ma dyslektyków (bo to klasy dla dzieci zdolnych) (UZ, ex post).

Brak kryteriów selekcji może powodować u uczniów poczucie zagubienia i trudności w wyborze dalszej ścieżki edukacyjnej, co było problemem jednej z respondentek:

Nie było takich testów też, które by jakieś predyspozycje mogły określić. Ja się bardzo dobrze uczyłam ze wszystkich przedmiotów, miałam bardzo dobre stopnie, więc też trudno powiedzieć, że jestem dobra w tym czy w tym (...). Nikt nawet mi nigdy nie powiedział, że jestem uzdolniona, byłam bardzo pracowita i obowiązkowa (UZ, ex post).

\section{Normalizacja}

Szkoła kładzie nacisk na adaptację uczniów do norm, rytuałów i standardów (myślenia, działania). Uczniowie zdolni wydają się odczuwać tę kwestię jako szczególnie dotkliwą, zwłaszcza w odniesieniu do wyrażanego przez nich niepokoju poznawczego, przejawiającego się w pytajności i intelektualnym nonkonformizmie.

No właśnie nie wspominam szkoły jako czegoś twórczego, kreatywnego; bardziej chodziło o wpisanie się w różne schematy życia szkolnego (UZ, ex post).

[The teachers] put a lot of pressure on such a person to bring him back to the regular way [in which] you're doing things (UZ, ex post).

Jak miałam dwanaście lat, chyba trzynaście, to Internet odkryłam, właśnie, i no, i zainteresowania właśnie tam rozwijałam, dyskusje na temat tego, co czytałam, oglądałam, natomiast tam prowadziłam, mhh... w (każdej) szkole, zwłaszcza na lekcji, zdarzyło mi się chyba raz spróbować (...) zanalizować, powiedzieć, właśnie przedyskutować i za każdym razem to nie wyszło (UZ, ex post).

Normalizujące praktyki ,wtłaczania w ramy” bywają dostrzegane także przez samych nauczycieli: 
Szkoła, która, no, którą my mamy... tak, nasz system oświaty oferuje pewien szablon, który w 20-, 30-osobowej grupie klasowej wygląda tak, że my po prostu w ten szablon staramy się wsadzić każde dziecko, również to zdolne (Nauczyciel).

\section{Terapia zajęciowa}

Zgodnie z oficjalnymi założeniami szkoła aktywnie wspiera rozwój talentów, wykorzystując innowacyjne strategie dydaktyczne. Niemniej dostrzega się wysiłki szkoły polegające na organizacji ukrytych form „terapii zajęciowej” dla uczniów zdolnych, którzy niekiedy zdają się swoją obecnością zakłócać regularny, rytualistyczny charakter szkolnego kształcenia. W tym kontekście uczeń zdolny bywa postrzegany przez nauczycieli jako uczeń nadmiernie aktywny, zakłócający swoją obecnością ład klasy szkolnej (np. przez stawianie pytań zaburzających monologowy charakter toku kształcenia), lub zniechęcony - wykazujący przejawy znudzenia i braku zdyscyplinowania, ponieważ próby siłowego dostosowania ucznia zdolnego do rutynowych transmisyjnych praktyk edukacyjnych wywołują u niego nudę, frustrację i spadek zaangażowania w uczenie się (Gallagher i in. 1997). $\mathrm{Z}$ tego powodu:

Łatwiej jest pracować nauczycielom z uczniem, który będzie robił to, czego nauczyciel chce, w takim utartym torze. A uczeń zdolny wychodzi poza tor, a myślę, że nauczyciel jeszcze tego nie trawi (Nauczyciel).

Bywa, że uczeń zdolny pada ofiarą nauczycielskiej „władzy nad mową”, jest pozbawiany możliwości swobodnej wypowiedzi, uciszany na zajęciach po to, aby nie zakłócał toku lekcji, nie wprowadzał zamieszania, a nawet - by nie zadawał pytań, które wybiegają poza dydaktyczne intencje nauczyciela w założeniu regulowane zakresem programu kształcenia. Nasi rozmówcy bardzo dobrze pamiętają sytuacje, gdy nie pozwolono im się wypowiedzieć, wymienić poglądami, zaciekawić tym, co w danym momencie ich pasjonowało:

My zawsze z rodzicami lubiliśmy dużo czytać, dużo rzeczy mnie interesowało, chciałam dużo wiedzieć... Więc jak coś przeczytałam, o czymś się dowiedziałam, chciałam się tym dzielić, ale to było tłumione... Często słyszałam, że: „ty już nie mów, my wiemy, że ty wiesz"... Więc tak naprawdę potem nauczyłam się, że nie warto się zgłaszać, bo i tak zostanę stłumiona. Raczej, jak uczyłam się czegoś nowego, było to już poza szkołą (UZ, ex post).

W tym sensie formy obecności ucznia zdolnego w klasie szkolnej można uznać za naznaczone przemocą symboliczną zaprzeczenie rzeczywistej idei kształcenia jako poszukiwania sensu, odkrywania i negocjacji znaczeń.

Zasada aktywnego wspierania uczniów zdolnych kłóci się także z działaniami szkoły wprowadzającymi formy „terapii zajęciowej” jako szczególnego sposobu (pozorowania) pracy z uczniem zdolnym. Ich zasadniczym celem jest przesycone (nie tylko) symboliczną 
przemocą wpisanie aktywności ucznia zdolnego w monotonny rytm transmisyjnych praktyk dydaktycznych, zorientowanych na tzw. „opanowanie materiału” przez uczniów; towarzyszyć im także może ukryty cel znalezienia jakichkolwiek form aktywności dla ucznia zdolnego, dostarczających - przynajmniej - pozorów jego zaangażowania: „W systemie klasowo-lekcyjnym najlepiej sprawdzają się metody pracy wykorzystujące samodzielną pracę ucznia: przygotowanie i prezentowanie referatów, rozwiązywanie dodatkowych zadań, a także współprowadzenie zajęć lekcyjnych z nauczycielem” (ORE 2012); „Wśród najbardziej podstawowych i najłatwiejszych w realizacji form dodatkowego wsparcia ucznia zdolnego należy wymienić zadawanie dodatkowych prac do samodzielnego przygotowania. Takie nadobowiązkowe zadania respondentom zdarza się realizować zarówno podczas zajęć lekcyjnych, kiedy reszta klasy pracuje nad opanowanym już przez nich materiałem, jak i, w głównej mierze, samodzielnie w domu" (ORE 2012). Rzeczywisty sens tych działań ujawnia się jednak w świetle tej wypowiedzi nauczycielskiej:

Trzeba mu dawać dodatkowe zadania, dlatego że szybciej wykonuje zadania niż pozostali uczniowie (Nauczyciel).

\section{Outsourcing i odświętne formy rzeczywistego uczenia się}

Szkoła przejawia opór wobec stosowania aktywnych strategii uczenia się, które są desygnowane poza obszar uczenia się „,codziennego”, pomimo wyników badań wskazujących na ich podstawowe znaczenie nie tylko w rozwoju tych szczególnie uzdolnionych (APA 2017; Lüftenegger i in. 2015), lecz każdego ucznia (Klus-Stańska 2000; Tomlinson 1996). W świetle raportu przygotowanego przez ORE: „w ramach zajęć pozalekcyjnych wykorzystywane są metody aktywizujące uczestników, tj. zajęcia warsztatowe realizowane w weekendy, samodzielne prowadzenie kółek dla rówieśników czy wyjazdy naukowe" (ORE 2011: 76). Praktykowane jest również prowadzenie zajęć dla uczniów zdolnych w ramach godzin dyrektorskich:

Dyrektorzy (...) mają godziny dyrektorskie, które mogą przekazać na pracę z takimi uczniami. Dodatkowe godziny dla nauczycieli, którzy chcą pracować z takimi dziećmi (...). Wtedy nauczyciele, może nie można powiedzieć, że budują jakąś indywidualną ścieżkę i dla takiego dziecka podsuwają jakieś ciekawsze zadania (UZ, ex post).

Wspieranie osiągnięć uczniów zdolnych nierzadko przyjmuje postać outsourcingu. Dzieje się tak wówczas, gdy domeny ich rozwoju upatruje się poza szkołą lub poza regularnym tokiem i czasem kształcenia szkolnego:

Ale te rzeczy, te rzeczy były mmh... zawsze poza tym obowiązkowym programem nauczania. To nie było coś, co działo się w czasie zajęć, w klasie, tylko zawsze to było coś, co działo się poza, czasem nawet poza szkołą. W jakichś publicznych albo prywatnych miejscach, jakieś dodatkowe zajęcia (UZ, ex post). 
Z pytań nauczycieli i eksperckich odpowiedzi zamieszczonych na forum ogólnokrajowego projektu ORE (2014) poświęconemu pracy z uczniem zdolnym przebija przekonanie, że szkoła z jej rytualistycznym modelem transmisji znaczeń nie jest adekwatnym środowiskiem rozwoju szczególnych uzdolnień, dlatego też praktyki ich wspierania powinny być w jakimś sensie delegowane poza dominujący tryb szkolnego kształcenia i realizowane w postaci zajęć pozalekcyjnych, indywidualnej pracy z nauczycielem-tutorem przygotowującym ucznia do olimpiad i konkursów, a także należy uzyskać głębsze wsparcie w działaniach rodziny i środowiska lokalnego:

Problem ucznia zdolnego na poziomie szkoły podstawowej występuje bardzo często. Nauczyciele nie zawsze potrafią pomóc uczniom w rozwijaniu ich zdolności, natomiast uczniowie ograniczają się do wykorzystania komputera jako maszynki do grania. Dlatego należy szukać innych ścieżek rozwoju. Warto zapisać dziecko na zajęcia pozalekcyjne. Jeśli w szkole nie ma takich możliwości, trzeba szukać poza szkołą (wypowiedź eksperta ORE).

Jedną z najskuteczniejszych metod rozwijania uzdolnień i kompetencji poprzez działanie jest metoda projektu edukacyjnego, stosowana w szkole, po zajęciach lekcyjnych (wypowiedź eksperta ORE) ${ }^{6}$.

Nauczyciel - tutor zleca takiemu uczniowi doskonalenie się w zakresie konkretnych tematów, spotyka się z nim po lekcjach i przedyskutowuje przerobione zagadnienia, zaleca dalsze ćwiczenia, często w porozumieniu z nauczycielem klasowym przekazuje mu dodatkowe materiały bądź inne prace klasowe (wypowiedź eksperta ORE).

Uczniowie zdolni uzyskują głównie wsparcie polekcyjne, co oznaczałoby, że regularny czas spędzony przez nich w szkole może być czasem „bezpowrotnie straconym dla rozwoju" (określenie za: Kwieciński 1995):

Bycie zdolnym, że bycie osobą, która chce coś zrobić dodatkowego albo ma taki potencjał, albo wewnętrzny pęd do wiedzy, nie wiem, jak to nazwać (...) - szkoła nie oferowała niczego, żeby to zaspokoić (UZ, ex post).

Trzeba to samemu zrobić (...). Kluby zainteresowań, języki dodatkowe, zajęcia sportowe (UZ, ex post).

Mój system był taki: jak najmniej jak najmniej chodzimy do szkoły (...) natomiast wszystko nadrabiam sama w domu (...). Uważałam to za jakąś stratę czasu po prostu. Wolałam zająć się czymś innym, czymś, co mnie bardziej w tym momencie interesowało. Albo może nie, może inaczej: po prostu wiedziałam, że z tych zajęć niewiele wynoszę (UZ, ex post).

${ }^{6}$ W sensie dydaktycznym metoda projektów jest raczej ogólną zasadą kształcenia opartą na poszukującej aktywności uczniów i jako taka powinna być stosowana w ramach regularnego toku kształcenia. 


\section{Hierarchizacja osiagnięć i praktyki wykluczania}

Podczas analiz zwrócono uwagę na incydentalną, choć wydaje się, że ważną obecność pewnego wątku pokazującego, że selekcja i identyfikacja uczniów zdolnych w szkołach o wysokim prestiżu lub szkołach dedykowanych kształceniu „talentów” (należą do nich szkoły artystyczne) mogą generować silne praktyki wykluczeń:

Podobnie było w szkole muzycznej. Byli ci, którzy jeździli na konkursy, i 90\% tych, którzy się nie liczyli (...). Odkąad Olka powiedziała, że już nie chce jeździć, w zasadzie przestała mieć lekcje fortepianu. Może po piętnaście minut każdego tygodnia (UZ, ex post).

Zestawiając ze sobą poziom oficjalnych deklaracji dotyczących celowości i praktyk wspierania ucznia zdolnego w polskiej szkole z polem praktyki edukacyjnej, dostrzega się pewną problematyczność statusu ucznia zdolnego jako kłopotliwego i niepasującego do zastanej rzeczywistości kulturowej szkoły, nastawionej na efektywność kulturowej transmisji i rywalizację na „trudnym rynku usług edukacyjnych”. W relacji do ideacyjnej warstwy PDUZ, w której zasadniczym elementem jest adekwatność oddziaływań kształcących do potrzeb gospodarki opartej na wiedzy - co na świecie jest traktowane raczej jako odejście od tradycyjnych wzorców kształcenia na rzecz stymulowania rozwoju umysłu (w tym kreatywności) ucznia w ramach konstruktywistycznych strategii kształcenia polska szkoła wydaje się stanowić krzywe zwierciadło dyskursu pedagogiki zdolności. Szkoła podejmuje pewne wysiłki, lecz idą one w kierunku pozorowania zaspokojenia specjalnych potrzeb edukacyjnych uczniów zdolnych, sprowadzają się więc do ,technicznego zagospodarowania" oraz instrumentalnego wykorzystania ich potencjału w zacieśnionej przestrzeni „tu i teraz”. W naszym przekonaniu kluczowa pod tym względem nie jest jednak kwestia potrzeby specjalnego traktowania uczniów zdolnych, lecz palące wyzwanie zmiany kulturowej mentalności szkoły idące w kierunku uznania naturalnej różnorodności ludzkich potencjałów i systematycznego budowania (konstruktywistycznie zorientowanej) kultury wzajemnego uczenia się w miejsce kultury nauczania, w której jak pokazują aktualne przykłady niektórych systemów edukacji ${ }^{7}$ - znajdują równorzędne miejsca uczniowie o zróżnicowanych poziomach potencjałów i osiągnięć.

\section{Literatura}

APA (2017), Top 20 Principles From Psychology For Prek - 12 Creative, Talented, And Gifted Students' Teaching And Learning. http://www.apa.org/ed/schools/teaching-learning/top-twentyprinciples.asp, 15.09.2018.

Borland J.H. (2003), The Death of Giftedness: Gifted education without gifted children. W: J.H. Borland (ed.), Rethinking Gifted Education. New York-London, Teachers College Press.

7 W krajach, takich jak Norwegia czy Finlandia, z doskonałym skutkiem promuje się integracyjne kształcenie uczniów zdolnych w ramach zróżnicowanej grupy, rezygnując w ogóle z etykiety „,uczeń zdolny”. 
Borland J.H. (2005), Gifted education without gifted children. The case for no conception of Giftedness. W: R.J. Sternberg, J.E. Davidson (eds.), Conceptions of Giftedness. New York, Cambridge University Press.

Dai D.Y. (2009), Essential Tensions Surrounding the Concept of Giftedness. W: L.V. Shavinina (ed.), International Handbook on Giftedness. Dordrecht, Springer.

Foucault M. (1997), Archeologia wiedzy. Warszawa, PIW.

Foucault M. (2006), Słowa i rzeczy. Archeologia nauk humanistycznych. Gdańsk, słowo/obraz terytoria. Freeman J. (2012), Losy zdolnych. Co się zdarza, kiedy zdolne dzieci dorastaja. W: W. Limont, J. Cieślikowska, D. Jastrzębska (red.), Zdolni w szkole, czyli o zagrożeniach i możliwościach rozwojowych uczniów zdolnych. Poradnik dla nauczycieli i wychowawców. Warszawa, ORE.

Gallagher J., Harradine C., Coleman M. (1997), Challenge or boredom: Gifted students'view on their schooling. „Roeper Review”, 3(19).

Habermas J. (1985), Interesy konstytuujace poznanie. „Colloquia Communia”, 2(19).

Karwowska-Sokołowska A. (2010), Pomoc państwa i instytucji pozarządowych dla dzieci zdolnych. Warszawa, Kancelaria Senatu RP.

Klus-Stańska D. (2000), Konstruowanie wiedzy w szkole. Olsztyn, Wydawnictwo UWM.

Kwieciński Z. (1995), Socjopatologia edukacji. Olecko, Mazurska Wszechnica Nauczycielska.

Luke A. (1997), Critical Discourse Analysis. W: L.J. Saha (ed.), International Encyclopedia of the Sociology of Education. Canberra, Australian National University.

Lüftenegger M., Kollmayer M., Bergsmann E., Jöstl G., Spiel Ch., Schober B. (2015), Mathematically gifted students and high achievement: the role of motivation and classroom structure. „High Ability Studies”, 2(26).

Margolin L. (1996), A pedagogy of privilege. „Journal for the Education of the Gifted”, 1(19).

Męczkowska-Christiansen A. (2018), Uczeń zdolny w perspektywie „dyskursu produkcyjnego”. W stronę krytycznej rewizji pedagogiki zdolności. „Problemy Wczesnej Edukacji”, 4(43).

Mędrzycka M., Zawadzka K. (2011), Aby nie gubić zdolności i talentów uczniów. Materiały edukacyjne z konwersatorium zorganizowanego $10.06 .2011 \mathrm{r}$. https://www.ore.edu.pl/materialy-do-pobrania/page/172/?download=1630\%3Aniezwyka-podr-program-nauczania-matematyki-dlaklas-iv-vi-szkoy-podstawowej\&start=1960, 23.11.2018.

ORE (2009), Wybrane metody i formy pracy z uczniem zdolnym (prezentacja dla dyrektorów szkót). Ośrodek Rozwoju Edukacji, Zespół ds. budowania KSWZiT. http://www.npdyrektorzy.pl/data/ various/files/metody_uczen_zdolny.pdf, 21.10.2019.

ORE (2011), Badanie elementów systemu pracy z uczniem zdolnym. Raport z badania IDI. Ośrodek Rozwoju Edukacji. https://www.npseo.pl/data/documents/3/237/237.pdf, 12.10.2019.

ORE (2012), Uczeń zdolny - analiza dostępnych narzędzi diagnostycznych. Ośrodek Rozwoju Edukacji. http://www.bc.ore.edu.pl/dlibra/docmetadata?id=461\&from=\&dirids=1, 12.10.2019.

ORE (2014), Pytania i odpowiedzi - archiwum projektu. Ośrodek Rozwoju Edukacji. https://www. ore.edu.pl/2014/12/pytania-i-odpowiedzi, 2.11.2019.

Ponchała K. (2017), Elementy zarządzania procesowego w kształceniu ucznia zdolnego w szkole licealnej. „E-mentor”, 4(71). http://www.e-mentor.edu.pl/mobi/artykul/index/numer/71/id/1312, 12.10.2019.

Reszke K. (2018), Uczeń zdolny w świadomości nauczyciela. Studium fenomenograficzne. Praca magisterska. Gdynia, Akademia Marynarki Wojennej.

Tomlinson C. (1996), Good teaching for one and all: Does gifted education have an instructional identity? „Journal for the Education of the Gifted”, 2(20). 